\title{
INDEPENDENT REVIEW OF ADMINISTRATIVE AGENCY DETERMINATIONS IN THE STATES: THE VITALITY OF THE BEN AVON RULE
}

"The long debate about de novo review versus restricted review is about ended; the celebrated Ben Avon case is of little interest except as history. . . .1 While Professor Davis' statement probably describes the present status of federal administrative law, ${ }^{2}$ several recent decisions militate against accepting it as an accurate portrayal of the state picture, at least as concerns utility rate regulation. ${ }^{3}$ The Ben Avon case ${ }^{4}$ is still (1950)

1. Davis, Scope of Revieze of Federal Administrative Action, 50 Cor. L. Rev. 559

2. See Railroad Comm'n v. Rowan \& Nichols Oil Co., 310 U.S. 573 (1940) (de novo review of state commission's oil pro-ration order denied even though contesting party claimed confiscation); FPC v. Hope Natural Gas Co., 320 U.S. 591, 602 (1944) ("If the total effect of the rate order cannot be said to be unjust and unreasonable, judicial inquiry . . . is at an end."); New York v. United States, 331 U.S. 284, 336 (1947) (after district court took evidence in rate case which they heard de novo on claim of confiscation, the Court said ".. . . if the . . . evidence was necessary to pass on the issue of confiscation, the case should have been remanded to the Commission ..."); see generally, Davis, supra note 1. But cf. Atlantic Coastline RR. v. Pub. Util. Comm'n, 77 F. Supp. 675 (E.D.S.C. 1948) (in action to enjoin enforcement of Public Utility Commission order on ground that it was confiscatory, party contesting order was entitled to trial de novo); Pichotta v. City of Skagway, 78 F. Supp. 999 (D.C. Alaska 1948) (in action to enjoin city from enforcing allegedly confiscatory rate order, party contesting the order had right to a trial de novo); Pittsburgh S.S. Co. v. Brown, 171 F.2d 175 (7th Cir. 1948) (action by employer to enjoin compensation order under Longshoremen's Compensation Act given trial de novo on appeal). The Pittsburgh case was decided on authority of Crowell v. Benson, 285 U.S. 22 (1932), a case related in many of its aspects to the Ben Avon case. See Schwartz, Does the Ghost of Crozell v. Benson Still Walk?, 98 U. of PA. L. Rev. 163 (1949).

3. Alabama Pub. Serv. Comm'n v. Southern Bell Tel. Co., 253 Ala. 1, 12, 42 So.2d 655, 662 (1949) (". . . a duty rests on the court to examine the order of the Alabama Public Service Commission on the issue of confiscation . . . and in this connection to exercise its independent judgment on both the facts and the law involved.") (citing the Ben Avon case); Port Smith v. Southwestern Bell. Tel. Co., 220 Ark. 70, 78, 247 S.W.2d 474, 479 (1952) (". . . we do examine, . . . to see that the order of the Commission does not amount to a confiscation of the property of the Utility. . .") (citing the Ben Avon case) ; Florida Power Corp. v. Smith, CCH 1950 UTIL. LAW REP. I16,157.01 (Fla., 1951) (". . . where the issue is whether the rates prescribed by public authority are confiscatory, the court is not bound to accept the findings of the rate-making authority though they are supported by substantial evidence, but may exercise its independent judgment upon the facts.") (citing the Ben Avon case) ; Georgia Pub. Serv. Comm'n v. Atlantic Gas Light Co., 205 Ga. 863, 876, 55 S.E.2d 618, 627 (1949) (“... where a public service commission prescribes rates under which the utility company affected claim that its property will be confiscated, the State must provide a fair opportunity for submitting the issue to a judicial tribunal for a determination upon its own independent judgment .. .") (citing the Ben Avon case) ; Lowell Gas Co. v. Dep't of Pub. Util., 324 Mass. $80^{\circ}, 88,84$ N.E.2d 811, 816, cert. denied, 338 U.S. 825 (1949) ("It must, therefore, be taken to be the law of this commonwealth ... that the Declaration of Rights guarantees to an owner, who alleges that confiscation of his property will result from a rate order of the department, a fair opportunity for submitting that issue to a court for determination upon its own independent judgment as to both law and facts. . ") (citing the Ben Avon case); Staten Island Edison Corp. v. Maltbie, 296 N.Y. 374, 381, 73 N.E.2d 705, 707 (1947) ("The Ben Avon case has never been overruled; on the contrary the principle that where constitutional rights of liberty or of property are involved due process requires independent judicial determination 
being cited and recognized as controlling by a sufficient number of states to merit an investigation of the apparent inconsistencies and contradictions in the area of judicial review of rate orders of state public utility agencies.

\section{The CASE}

The Ben Avon case involved a rate order of the Pennsylvania Public Service Commission which fixed the maximum rates to be charged by the Ohio Valley Water Company. The company alleged error in the commission's findings and appealed to the Superior Court on the ground that adherence to the order would result in a confiscation of its property. The Superior Court reversed ${ }^{5}$ the commission's order on the ground that the commission had erred in its findings relating to the value of the company's plant and therefore had not properly computed a fair return on property. This holding was in turn reversed by the Pennsylvania Supreme Court ${ }^{6}$ which held that as there was substantial evidence to support the commission's findings, such findings were binding on the court. On further appeal, the United States Supreme Court reversed ${ }^{7}$ the Pennsylvania result, holding that where the owner of the property affected claims that confiscation of his property will result from an administrative agency's order, the Due Process Clause of the Fourteenth Amendment requires that the state provide for an independent judicial review of both the law and the facts involved in the order, and that a review limited to an inquiry as to whether there was substantial evidence to support the commission's findings was insufficient to protect the constitutional rights of the complaining party.

Despite the storm of criticism which followed the Ben Avon decision, ${ }^{8}$ the case was later reaffirmed, although somewhat modified, by the Supreme Court in Saint Joseph Stockyard Packing Co. $v$. United States. ${ }^{9}$ The Court again held that in cases involving claims of confiscation resulting from administrative agency determinations, an independent judicial review of the order was to be afforded the claimant, but added that the findings of the agency after hearings on the subject should be accorded consider-

of the constitutional question in the courts has been reaffirmed.") ; Valley \& Siletz R.R. v. Flagg, 195 Ore. 683, 714, 244 P.2d 639, 654 (1952) (". . . in cases which are based upon averments of confiscation the courts try the issues de novo..."); State v. Dep't of Pub. Serv., 19 Wash. 2d 200, 218, 142 P.2d 498, 508 (1943) (". . if the owner claims confiscation of his property will result, the State must provide a fair opportunity for submitting that issue to a judicial tribunal for determination upon its independent judgment as to both law and facts . . .") (citing the Ben Avon case).

4. Ohio Valley Water Co. v. Ben Avon Borough, 253 U.S. 287 (1920).

5. Ben Avon Borough v. Ohio Valley Water Co., 68 Pa. Super. 561 (1917). (1918).

6. Ben Avon Borough v. Ohio Valley Water Co., 260 Pa. 289, 103 Atl. 744

7. Ohio Valley Water Co. v. Ben Avon Borough, 253 U.S. 287 (1920).

8. See authorities collected in Comment, 39 Mrch. L. Rev. 438, 439 n.3 (1941); Davis, Administrative LAW, 919 n.222 (1951); Wiel, Administrative Finality, 38 HARV. L. REv. 447, 464 n.47 (1925).

9. 298 U.S. 38 (1936), 35 MICH. L. Rev. 159, 15 TEx. L. Rev. 128. 
able weight. This dicta provided one method, adopted later by many states, of avoiding the full effect of the Ben Avon rule. ${ }^{10}$

The legal literature that has grown up around the Ben Avon case is voluminous. ${ }^{11}$ The case has been analyzed many times as to both its legal and logical correctness and further analysis from this approach would be repetitious. The extended discussions, however, have failed to consider many relevant problems still existent in the states. Do many states still regard the Ben Avon case as controlling? If this is answered affirmatively why do some states follow it and not others (since the doctrine is purportedly based on a federal constitutional requirement)? To what extent do those states that purport to follow the Ben Avon rule actually do so in terms of a truly "independent" review? To what type of state administrative action is the rule applied? What are the arguments for and against the doctrine?

\section{The Difference Between State and Federal Law on the Problem}

The Supreme Court has never expressly overruled the Ben Avon case although certainly it has retreated from its original position to a considerable degree. ${ }^{12}$ This gives rise to one of the more perplexing problems surrounding the Ben Avon case: the question of why the case has more vitality in the state courts than in the federal courts. ${ }^{13}$ This is particularly noteworthy when it is remembered that the Ben Avon scope of review was required to satisfy the Due Process Clause of the Federal Constitution. ${ }^{14}$ While there have been some recent decisions in lower federal courts apparently reaffirming the Ben Avon rule, ${ }^{15}$ the generally accepted view is that it is no longer important in the federal courts. This might be due to a tendency in the federal courts today to emphasize procedural due process within administrative agencies themselves. The Johnson Act of $1934^{16}$ is undoubtedly a contributing factor. It provides that federal district courts shall not enjoin or otherwise interfere with rate orders of state administrative agencies where the requirements of procedural due process (e.g., reasonable notice and fair hearing) have been provided, and where an effective remedy (there is no mention of de novo review) is available in the state courts. Before the passage of this Act the federal courts were used to obtain an independent review of alleged confiscation. Since the passage of the Act the burden of so protecting the persons

10. See text beginning at note 64 infra.

11. See note 8 supra; see also, Notes, 28 N.Y.U.L. Rev. 417 (1953); 57 YALE L.J. 639 (1948).

12. Cases cited note 2 supra; Davis, note 1 supra.

13. Cases cited note 3 supra.

14. However, it should be noted that in some states the independent review requirement has been based on other than federal constitutional grounds. See text beginning at note 56 infra.

15. Atlantic Coastline R.R. v. Pub. Util. Comm'n, 77 F. Supp. 175 (E.D.S.C. 1948); Pickotta v. City of Skagway, 78 F. Supp. 999 (D. Alaska 1948).

16. 48 Stat. 775 (1934), as amended, 28 U.S.C. $\$ 1342$ (Supp. 1952). 
affected by the agency orders has shifted mainly to the state courts. ${ }^{17}$ This Act combined with the Supreme Court's apparent retreat from the Ben Avon doctrine might be the reason for the de-emphasis of the Ben Avon doctrine in the federal courts. Also, since the passage of the Administrative Procedure Act, ${ }^{18}$ there seems to be an awareness in federal courts of a congressional desire to limit the role of the judiciary in its relations with administrative agencies. This thought might well have carried over into the relations of the federal courts with state agencies. On the other hand, the state courts are closer to the utilities and other persons affected by the orders and are more likely to be influenced by any pressures that can be brought to bear. There may also be a cognizance on the part of the state courts that the state agencies are less expert than their federal counterparts (admittedly they handle fewer cases and are usually lower paid) and, therefore, there is need for an additional check in the form of a wider scope of review over the agency's decisions, i.e., a Ben Avon type of review. However, the situation when viewed from a purely doctrinal viewpoint remains anomalous.

\section{The States and Ben Avon: Possible Bases for AdHerence to or REJECTION OF THE DOCTRINE}

There is no doubt that many states at least purport to follow the Ben Avon doctrine. ${ }^{19}$ The obvious explanation is that the case has never been expressly overruled. However, it is equally clear that many states no longer follow the doctrine, ${ }^{20}$ nor do most of the federal courts. ${ }^{21}$ Such

17. See United Gas Corp. v. City of Monroe, 46 F. Supp. 45, 46 (W.D. Ia. 1942). ("We may take notice of the fact that the purpose of this [act] . . . was to stop a widespread practice by non-resident corporations of taking cases involving local rates into Federal courts, and to compel a resort to the State courts except where the rate making authority had, in effect, denied due process of law, by failing or refusing to accord "reasonable notice and hearing." ").

18. 60 Stat. 237-44, 5 U.S.C. $\$ \$ 1001-1011$ (1946).

19. See note 3 supra.

20. Glenwood Light \& Water Co. v. Glenwood Springs, 98 Colo. 340, 55 P.2d 1339 (1936) (findings of commission on disputed questions of fact are final under statutory provision dealing with review of rate orders) ; Denver Producing \& Refining Co. v. State, 199 Okla. 171, 184 P.2d 961 (1947) (". . . it would be presumptuous of our courts, on the basis of conflicting testimony, to deem the view of the administrative tribunal, acting under legislative authority, offensive to the Fourteenth Amendment. . Id. at 174, 184 P.2d at 964 [quoting Railroad Comm'n v. Rowan \& Nichols Oil Co., 310 U.S. 573, 581]) ; Chicago, M., St. P. \& P. Ry. v. Pub. Serv. Comm'n, 260 Wis. 212, 219, 50 N.W.2d 416, 419 (1951) (". . we must accept findings of fact of the commission, even where a constitutional question is involved, if the commission's findings are supported by substantial evidence." This statement was made in a case involving a claim that the order contested would result in a confiscation of property in violation of the Fourteenth Amendment.) See Joy v. Winstead, 70 Idaho 232, 242, 215 P.2d 291, 296 (1950) (court can protect constitutional rights without independent review where there is claim of confiscation); Michigan Bell Tel. Co. v. Michigan Pub. Serv. Comm'n, 332 Mich. 7, 50 N.W.2d 826 (1952) (court will look only to see if total effect of rate order attacked as confiscatory is unreasonable).

21. Cases cited note 2 supra. 
jurisdictions as Alabama, ${ }^{22}$ Washington, ${ }^{23}$ New York ${ }^{24}$ and Texas ${ }^{25}$ are found at least claiming to follow the doctrine while Colorado, ${ }^{26}$ Oklahoma ${ }^{27}$ and Wisconsin ${ }^{28}$ have apparently rejected it. While no recent cases directly on point have been found, it is probable that Michigan ${ }^{29}$ and Idaho ${ }^{30}$ have also disclaimed the doctrine. Pennsylvania, the state in which the case arose, still adheres to it, ${ }^{31}$ although with some modifications as to the "independence" of the review..$^{32}$ There should be some logical reason why some states have adhered to the Ben Avon rule while others have rejected it. If a rationale can be discovered it can both point up the substantive reasons behind a particular state's decisions on the problem, and aid in predicting future results. Inquiry reveals, however, that it is difficult, if not impossible, to categorize according to any logical basis the type of cases or the jurisdictions that do and do not follow the rule. The only generalization that can safely be made is that most of the cases in which the rule has been applied have been rate cases ${ }^{33}$ although the doctrine has been invoked in a few other instances such as licensing, ${ }^{34}$ and orders to restore corporate assets. ${ }^{35}$ Other possible considerations are discussed below, but prove to be of little aid in a search for a rationale.

The Expertise Factor.-One argument frequently raised against adherence to the Ben Avon rule is that the scope of review should depend to a large extent upon "the comparative qualification of a court and agency to decide the particular question." 38 Therefore, since the agencies are more skilled than the courts to deal with most of the problems involved in making a rate order, the agency should as far as possible control the result and the scope of review of the court should be limited. Related to this argument is the theory that those states with the more expert agencies would

22. Pub. Serv. Comm'n v. Southern Bell Tel. Co., 253 Ala. 1, 42 So.2d 655 (1949).

23. State v. Dep't of Pub. Serv., 19 Wash. 2d 200, 142 P.2d 498 (1943).

24. Staten Island Edison Corp. v. Maltbie, 296 N.Y. 374, 73 N.E.2d 705 (1947).

25. Cf. Lone Star Gas Co. v. State, 137 Tex. 279, 153 S.W.2d 681 (1941). But cf. Trapp v. Shell Oil Co., 145 Tex. 323, 198 S.W.2d 424 (1946).

26. Glenwood Light \& Water Co. v. Glenwood Springs, 98 Colo. 340, 55 P.2d 1339 (1936). (1947).

27. Denver Producing \& Refining Co. v. State, 199 Okla. 171, 184 P.2d 961

28. Chicago, M., St. P. \& P. Ry. v. Pub. Serv. Comm'n, 260 Wis. 212, 50 N.W.2d 416 (1951). (1952).

29. Michigan Bell Tel. Co. v. Pub. Serv. Comm'n, 332 Mich. 7, 50 N.W.2d 826

30. See Joy v. Winstead, 70 Idaho 232, 215 P.2d 291 (1950).

31. See Peoples Natural Gas Co. v. Pub. Util. Comm'n, $153 \mathrm{~Pa}$. Super. 475, 34 A.2d 375 (1943) ; Solar Electric Co. v. Pub. Util. Comm'n, 137 Pa. Super. 325, 9 A.2d 447 (1939).

32. See text after note 64 infra.

33. See note 3 supra. (1942).

34. See, e.g., Laisne v. State Board of Optometry, 19 Cal. 2d 831, 123 P.2d 457

35. First Industrial Loan Co. v. Daugherty, 148 P.2d 439 (Cal. App. 1944).

36. Davis, Administrative Law 927 (1951). 
be the ones less likely to follow the Ben Avon rule with its greater control of the agency by the court. Expertness of an agency is, of course, difficult to ascertain but it would seem that the agencies with the highest pay and the most business (therefore with the most experience) should be among the most expert. The commissions in New York and Massachusetts are two of the highest paid in the country. ${ }^{37}$ These two states are also two of the largest in regard to the number of utilities regulated, and the amount of utility business done. ${ }^{38}$ However, both of these states follow the Ben Avon rule, ${ }^{39}$ while Oklahoma ${ }^{40}$ and Colorado, ${ }^{41}$ two of the smaller states with less busy and lower paid commissions have rejected it. Therefore, the factor of administrative expertise seems to have little relation to a court's decision to accept or reject the Ben Avon doctrine.

Administrative Procedure Legislation as a Factor.-Another factor that has been recognized in determining the weight to be given to administrative agency determinations and consequently the type and scope of review to be given to orders is the procedural safeguards afforded parties in the agency hearings. "Even though procedural safeguards cannot validate an unconstitutional delegation, they do furnish protection against an arbitrary use of properly delegated authority." 42 It would seem that states with more "advanced" administrative procedure legislation, those with assurance of procedural due process within the agencies, might be less apt to follow the doctrine with its additional judicial control over the agencies than would states with less adequate procedural safeguards. Because of the wide variations among the states in administrative procedure legislation it is of little help to classify the states on this basis. Some states have adopted general administrative procedure codes, ${ }^{43}$ others deal with only some aspects of administrative law, ${ }^{44}$ and other states have enacted special procedures for each individual agency. ${ }^{45}$ Thus an attempt at classification on this basis would be either so generalized as to be valueless or so specific as to be unwieldly. ${ }^{46}$ As an example of the futility of trying to predict whether or not a jurisdiction will follow Ben Avon on

37. Book of the States 441 (1952-1953).

38. Statrstical Abstract of the United States 481, 487 (1952).

39. Staten Island Edison Corp. v. Maltbie, 296 N.Y. 374, 73 N.E.2d 705 (1947); Lowell Gas Co. v. Dep't of Pub. Util., 324 Mass. 80, 84 N.E.2d 811 (1949), cert. denied, 338 U.S. 825 (1949). (1947)

40. Denver Producing \& Refining Co. v. State, 199 Okla. 171, 184 P.2d 961

41. Glenwood Light \& Water Co. v. Glenwood Springs, 98 Colo. 340, 55 P.2d 1339 (1936).

42. United States v. Royal Rock Cooperative, 307 U.S. 533, 576 (1939).

43. E.g., N.D. Rev. CoDE \$22 (1943).

44. E.g., WIs. Stat. §227.01 (1951).

45. E.g., N.Y. Pub. SERv. LaW § 112.

46. See generally Heady, Administrative Procedure Legistation in the States (1942); Harris, Administrative Practice and Procedure and Comparative State Legislation, 6 OkLA. L. REv. 29 (1953); Nathanson, Recent Statutory Developments in State Administrative Law, 33 Iowa L. Rev. 252 (1948). 
the basis of its statute, the differences in phrasing, flavor and content of the Public Utility Codes of Pennsylvania, Wisconsin and Massachusetts on the subject of judicial review of commission orders may be cited. The Massachusetts statute gives the reviewing court power to ". . . review, modify, amend or annul a ruling or order of the commission. . . ."; 4 47 the Pennsylvania statute only authorizes the court to "dismiss the appeal, or vacate the order . . . in whole or in part." 48 The Wisconsin statute permits the court to "affirm the decision of the agency, or . . . reverse or modify. . . ." 49 The Pennsylvania statute states as the grounds for reversal of a commission order "error of law or lack of evidence to support the finding ... of the commission, or violation of constitutional rights." ${ }^{50}$ The Wisconsin statute gives as grounds for reversal the fact that the agency order is "contrary to constitutional rights," or "in excess of statutory authority . . . or affected by other error of law," or "made upon unlawful procedure," or "unsupported by substantial evidence," or that it is "arbitrary or capricious." 51 But the Massachusetts statute merely states "unlawfulness" as the ground for overruling a commission order. 52

Comparison of the above statutory clauses would seem to indicate a similarity of legislative intent in Pennsylvania and Wisconsin. Massachusetts, on the other hand, would seem to have a scope of review substantially different from either Wisconsin or Pennsylvania. The fact is, however, that despite their similar statutory provisions, Pennsylvania purports to follow the Ben Avon case while Wisconsin does not.53 Furthermore, Massachusetts definitely adheres to a Ben Avon scope of review ${ }^{54}$ although its statute is unlike Pennsylvania's. Thus the statutory articulation of scope of review has little bearing on the instant problem.

Moreover, a reading of the cases on point discloses none in which the inadequacy of the hearing before the commission was the primary reason for reversal of a commission order. In fact an unfair hearing has never appeared as the main ground of an appellant's case. Thus it appears that the unfairness of the administrative procedure within the agencies is not a reason why courts have exercised a wide scope of review. It should also be noted that the federal courts would not be precluded by the Johnson Act from hearing any cases based on such a complaint. ${ }^{55}$

47. Mass. Ann. Laws c. $25, \S 5$ (1952).

48. Pa. Stat. Ann. tit. 66, $\$ 1437$ (Purdon 1941).

49. WIS. Stat. $\$ 227.20$ (1951).

50. Pa. Stat. Ann. tit. $66, \S 1437$ (1941).

51. Wis. Stat. $\$ 227.20$ (1951).

52. Mass. Ann. Laws c. $25, \S 5$ (1952).

53. Compare Solar Electric Co. v. Pub. Util. Comm'n, $137 \mathrm{~Pa}$. Super. 325, 354, 9 A.2d 447, 464 (1939), with Chicago, M. St. P. \& P. Ry. v. Pub. Serv. Comm'n, 260 Wis. 212,50 N.W.2d 416 (1951).

54. Opinion of the Justices, 328 Mass. 679, 106 N.E.2d 259 (1952); Lowell Gas Co. v. Dep't of Pub. Util., 324 Mass. 80, 84 N.E.2d 811 (1949), cert. denied, 338 U.S. 825 (1949).

55. See text at note 16 supra. 
This, plus the fact that there is substantial similarity in the statutes in requiring a hearing and notice, lends little to the belief that the level of administrative due process among the states bears a significant relation to the states' position on the Ben Avon rule.

State Constitutions as a Factor.-Certain state courts have given as a reason for following the Ben Avon rule the theory that even if the Federal Constitution does not require an independent judgment by the courts on claims of confiscation, their state constitutions do so require. ${ }^{56}$ Therefore, another basis for reconciling the positions of the various states on this problem is suggested. Examination should be made of the similarities, if any, in the constitutions of the states on one side of the fence and their differences, if any, from the constitutions of the states that have taken a different stand on the problem.

In an Opinion of the Justices, ${ }^{57}$ the Massachusetts court rested its decision substantially on state constitutional grounds, contending that the First, Tenth and Eleventh Articles of the Massachusetts Constitution required an independent review of agency action. The First Article contains the statement, found in almost all state constitutions, that all men have the right to enjoy life, liberty and maintain property. The Eleventh Article states that all ought to have remedies for wrongs done them and is also found in almost all state constitutions. The Article which can be construed most easily to support the result reached is the Tenth, which states that no man shall have his property taken from him except by a representative body. However, it would seem that an administrative body, as an arm of the legislature, is at least as representative as the courts.

California ${ }^{58}$ based its adherence to Ben Avon on state constitutional grounds which differed from those of Massachusetts. The California court argued that failure to follow the Ben Avon rule would result in a deprivation of property without due process of law. A due process provision is again found in all state constitutions. Another ground suggested in the decision was the provision in the California Constitution relating to the separation of powers and prohibiting any body, except certain enumerated courts, from exercising state-wide judicial powers. ${ }^{59}$ By labelling the agency action as "judicial" the court brought such action under the constitutional prohibition and required a de novo trial of the issues already decided by the agency. The court apparently failed to consider that its judicial power would not be usurped if the Ben Avon doctrine were not followed. There still is a power of review ("sustantial evidence"), which while not so wide as a Ben Avon review, is nevertheless effective. By

56. Lowell Gas Co. v. Dep't of Pub. Util., 324 Mass. 80, 84 N.E.2d 811, cert. denied, 338 U.S. 825 (1949); Laisne v. State Board of Optometry, 19 Cal. 2d 831, 123 P.2d 457 (1942).

57. 328 Mass. 679, 106 N.E.2d 259 (1952).

58. Laisne v. State Board of Optometry, 19 Cal. 2d 831, 123 P.2d 457 (1942).

59. Calif. Const. Art. III, $\S 1 ; \mathrm{VI}, \S 1$. 
exercising such a review the courts would at the same time preserve their judicial function and guard against any violations of due process. The reasoning of the California court also seems to ignore the difference between the "judicial" power (that which is vested in the courts) and a "quasi-judicial" power (that which is frequently exercised by administrative agencies)..$^{60}$ Separation of powers provisions are found in almost all state constitutions; furthermore, the United States Supreme Court has recognized, in a case arising before Ben Avon, that "[e]ven where it is essential to maintain strictly the distinction between the judicial and other branches of government, it must still be recognized that the ascertainment of facts, or the reaching of conclusions upon evidence taken in the course of a hearing of parties interested, may be entirely proper in the exercise of executive or legislative, as distinguished from judicial powers. . . ." 61

While it may be commendable for the states to require more protection of property under their constitutions than is required under the Federal Constitution, the Ben Avon case itself, while incorporated in the courts' opinions is unnecessary to the result. Because of the general similarities in state constitutions it appears that arguments for and against following the Ben Avon rule based on state constitutional grounds are used to bolster previously arrived at conclusions; no real basis for classification on such grounds exists. ${ }^{62}$

The Failure of the Search for a Basis of Classification.-Since they apparently were not considered by the courts in deciding whether or not to follow the rule, factors such as the degree of expertness of a commission,

60. The concept of a "quasi-judicial" power and its rationale is by no means a new one.

". . . there is a distinction, which the courts have observed, between judicial investigation and decisions concerning the relative rights of individuals and the rights of individuals and the public.

"Power to hear and determine matters . . . affecting public and private rights is conferred upon, and exercised by, administrative officers.

". . . if all quasi judicial power and discretion were taken from administrative . officers, and every question of this kind ... had to be submitted to law trial, the courts would be incumbered with useless litigation, and the administration of the government would become so expensive that it would be intolerable." Bellingham Bay Imp. Co. v. New Whatcom, 20 Wash. 53, 58, 54 Pac. 774, 775 (1898); see also Murray v. Hoboken Land \& Imp. Co., 18 How. 272 (U.S. 1855). For extended discussions of "Quasi-Judicial" see McGovney, Administrative Decisions and Court Review Thereof, 29 CALIF. L. Rev. 110 (1941); Wade, "Quasi Judicial" and its Background, 10 CAMB. L.J. 216 (1949).

61. Louisville \& N.R.R. v. Garrett, 231 U.S. 298, 301 (1913).

62. Another reason why certain states follow the rule and others do not might be that those states that had confiscation cases arising during the period closely following the decision in the Ben Avon case felt compelled to follow it and thereby established precedent to which they owe fealty, while states which did not have cases arising on point until the Ben Avon case fell from favor have no such "compelling" precedents to follow. In Massachusetts there were affirmations of the Ben Avon rule by the highest court of the state in 1925. Opinion of the Justices, 251 Mass. 569, 147 N.E. 681 (1925). This was also true in Pennsylvania. Bangor Water Co. v. Pub. Serv. Comm'n, 82 Pa. Super. 48 (1923); Borough of Lewistown v. Pub. Serv. Comm'n, $80 \mathrm{~Pa}$. Super. 528 (1923). However, this was evidently not the case in New York. Compare, People ex rel. Consolidated Water Co. v. Maltbie, 275 N.Y. 357, 9 N.E.2d 961, aff'd, 303 U.S. 158 (1937), with Staten Island Edison Corp. v. Maltbie, 296 N.Y. 374, 73 N.E.2d 705 (1947), 96 U. of PA. L. REv. 266. 
or the administrative procedure safeguards of the jurisdiction have not proved helpful in explaining or predicting the judicial attitude toward the Ben Avon rule in a particular jurisdiction. However, the possibility of using these factors as an argument in a particular case still exists. The Ben Avon case is "there"; it has never been overruled; it should certainly be cited to a court if the problem it deals with is under consideration; but there is little rational basis given in the existing opinions for adoption or rejection of the rule. ${ }^{63}$

\section{Limitations on the "INDEPENDENCE" of Review}

Although many state courts still profess to follow the Ben Avon case a more discerning analysis of the cases and statutes involved lends credibility to the belief that the Ben Avon rule has few adherents today. Reference has been made previously to the Supreme Court's approval, in the Saint Joseph Stockyard case, ${ }^{64}$ of giving great weight to the agency's findings. This practice has been adopted by most states either by establishing a presumption that the findings of the agency involved are prima facie correct, ${ }^{65}$ or by stating that the one contesting the order has to come forward with "clear and convincing" proof of confiscation. ${ }^{66}$ Both of these procedures place a burden of proof on the contesting party which is not in accord with the theory of a de novo hearing, although they may be reconciled with the theory of "independent" review. ${ }^{67}$

Another device that is used to avoid the full effect of the Ben Avon rule is the restriction of the evidence which can be brought before the court on appeal to that contained in the record of the agency hearing. ${ }^{68}$ There is little doubt as to the constitutionality of such a restriction. ${ }^{69}$ The device has been modified in some states so that new evidence can be offered to the court, but the court must send the case back to the agency for reconsideration in the light of the new evidence, and only if the original order is reaffirmed can the new evidence be brought before the court in a new appeal..$^{70}$

63. Professor Dickinson's statement that ". . . there are no iron-clad rules applicable to the cases in general, to forecast with certainty how far a court will review in a given case" would still seem to be valid. Dickinson, Apministratrve JUSTICE AND THE Supremacy of LAW 71 (1927). See also Schwartz, Does the Ghost of Crozvell v. Benson Still Walk?, 98 U. of PA. L. Rev. 163 (1949).

64. 298 U.S. 38 (1936).

65. See, e.g., Mass. Ann. Laws c. 25, § 5 (1952) ; Florida Power Corp. v. Smith, CCH 1950 UTIL. LAw REP. II 16,157.01 (Fla. 1951); Incorporators of Service Gas Co. v. Pub. Serv. Comm'n, 126 Pa. Super. 381, 190 At1. 653 (1937).

66. See Lone Star Gas Co. v. State, 137 Tex. 279, 153 S.W.2d 681 (1941).

67. A "de novo" trial connotes a completely new proceeding with everything done afresh; an independent review, however, can admit of certain restrictions as to the material upon which the independent judgment is to be exercised. This distinction has been recognized by some courts, although the problem resolves itself to a question of labels. For a discussion of the differences between a trial de novo and an independent review see Trayner, J., concurring and dissenting in Dare v. Board of Medical Examiners, 21 Cal.2d 790, 803, 136 P.2d 304, 311 (1943).

68. Pa. Stat. Ann. tit. 66, $\$ 1437$ (Purdon 1941) ; Mass. Ann. Laws c. 25, $\S 5$ (1952), as amended by Mass. Gen. LAws c. 575 (effective Sept. 1, 1953).

69. See Alabama Pub. Serv. Comm'n v. Southern Ry., 341 U.S. 341, 348 (1951).

70. See, e.g., N.D. Rev. Cone $\$ 28-3219$ (1943) ; MASs. Ans. Laws c. 25 , § 5 , as amended by MASS. GEN. LAws c. 575 (effective Sept. 1, 1953). 
The problem of restriction of the evidence heard on appeal is an important one. After the recent reaffirmation of the Ben Avon rule in Massachusetts, ${ }^{71}$ and after the advisory opinion by Massachusetts' highest court that a proposed law denying independent review would be unconstitutional, ${ }^{72}$ the Massachusetts Public Utility Commission considered the problem so pressing that it proposed emergency legislation restricting evidence that can be heard by the reviewing court to that of the commission record. This proposal was adopted by the state legislature and has recently gone into effect. ${ }^{73}$ Litigation on the problem of restricting evidence is now pending in Michigan ${ }^{74}$ and Indiana ${ }^{75}$ and the counsel for the Public Utility Commissions in both states have expressed the opinion that if evidence in addition to that contained in the commission record were allowed to be introduced before the court, the commissions' operations would be greatly hindered. (Note that neither state follows the Ben Avon rule.) ${ }^{78}$ Their fear is that if the evidence on review is not restricted, the attorneys for the opposing parties will withhold evidence until the case is brought into court so as to gain the element of surprise.

In response to a questionnaire sent to a number of attorneys for utilities and for other companies which have dealings with commissions, ${ }^{77}$ one attorney stated that he would probably attempt such strategy. However, even though in many states discovery procedures similar to those in the federal code are not in force, it seems that under present day discovery procedure the surprise element would be vitiated. ${ }^{78}$ It would also seem probable that in most cases attorneys would feel that their clients would be better served by getting all the evidence before the commission so as to get the most favorable order and avoid the additional expense consequent to an appeal. ${ }^{79}$ Once the courts are restricted so that only evidence that was brought before the commission can be heard, and there

71. Lowell Gas Co. v. Dep't of Pub. Util., 324 Mass. 80, 84 N.E.2d 811 (1949), cert. denied, 338 U.S. 825 (1949).

72. Opinion of the Justices, 328 Mass. 679, 106 N.E.2d 269 (1952).

73. Mass. Gen. Laws c. 575 (effective Sept. 1, 1953).

74. Letter from Robert A. Deregonski, Counsel for the Michigan Public Service Commission, on file in the Biddle Law Library, University of Pennsylvania Law School, 3400 Chestnut St., Phila., Pa.

75. Letter from James T. Robison, Public Counselor for the State of Indiana, on file in the Biddle Law Library, supra note 74 .

76. Pub. Serv. Comm'n v. Indianapolis Ry., 225 Ind. 30, 39, 72 N.E.2d 434, 438 (1947) ; Pub. Serv. Comm'n v. Indiana Bell Tel. Co., 112 N.E.2d 751 (Ind. 1953); City of Detroit v. Michigan R.R. Comm'n, 209 Mich. 395, 177 N.W. 306 (1920).

77. All such responses are on file in the Biddle Law Library, supra note 74.

78. Procedures such as pre-trial conferences, the increased taking of depositions and interrogatories and other discovery devices would all tend to eliminate the surprise element. While not in force in all jurisdictions, the growing tendency is to adopt them. See Clark, Code Pleading \$ 89 (1947).

79. One attorney noted that although there might be a difference in presentation of the case on appeal, there probably would be no difference in presentation before the commission because most commissions set rates according to certain formulae. Most attorneys, therefore, concentrate on trying to fit their facts to the particular formula adopted in that jurisdiction. 
is a presumption that the agency order is correct, the degree of independence with which the court can operate is diminished considerably. ${ }^{80}$ However, even under the above mentioned restrictions on the independence of the review there is no need for the person contesting the order to prove that it is arbitrary and unreasonable as he must do in states that do not follow the Ben Avon rule, 81 and the courts are not bound to accept an order as valid even though there is substantial evidence to support it. ${ }^{82}$ By the devices of restriction of evidence and presumption of agency correctness state courts can guard against a reversal on the basis of a reaffirmation of the Ben Avon rule by the Supreme Court and at the same time guard against such dangers, allegedly inherent in following the Ben Avon doctrine, as frequent and time consuming appeals to the courts, the substitution of the judgment of the courts for the expert knowledge of the agencies, the withholding of evidence by attorneys until appeal is taken, and an invasion by the courts of the province of the legislature.

\section{The Property Which the Doctrine Protects}

Another puzzling fact in this field is the apparent restriction of the application of the doctrine, in those states that purport to follow the rule, to the field of utility rate regulation. ${ }^{83}$ It is true that some states that follow the Ben Avon rule have a wide scope of review, or even a de novo review in non-rate order cases involving large companies. ${ }^{84}$ However, most recent cases in which the Ben Avon case has been cited approvingly are rate cases. There may be an explanation as to why the rule has not been applied to the typical small business. The small businessman or private citizen adversely affected by an agency order is probably less willing to bear the expense of appeal to the courts than is the large utility. But this does not explain why the rule has not been applied in many cases, other than

80. Since the degree of "independence" of the review given is under discussion, the question arises as to just how far the courts do go into the evidence before them on appeal. Do the courts state that they are giving an independent review as an incantation against reversal on further appeal or is there truly an independent review and judgment exercised by the courts when there is a claim of confiscation with some merit to it? Judging from the length of the opinions and the amount of analysis presented it would appear that the courts examine the problems very thoroughly, and even where there appears to be substantial evidence to support the commission's order a truly independent review of the facts and the law is evident. See, e.g., Staten Island Edison Corp. v. Maltbie, 296 N.Y. 374, 73 N.E.2d 705 (1947); Lowell Gas Co. v. Dep't of Pub. Util., 324 Mass. 80, 84 N.E.2d 811 (1949), cert. denied, 338 U.S. 825 (1949); Alabama Pub. Serv. Comm'n v. Southern Bell Tel. Co., 253 Ala. 1, 42 So.2d 655 (1949).

81. Compare State v. Dep't of Pub. Serv., 19 Wash.2d 200, 142 P.2d 498 (1943) with Michigan Bell Tel. Co. v. Michigan Pub. Serv. Comm'n, 332 Mich. 7, 50 N.W.2d 826 (1952).

82. Compare Lowell Gas Co. v. Dep't of Pub. Util., 324 Mass. 80, 84 N.E.2d 811 (1949) with Chicago, M., St. P. \& P. Ry. v. Pub. Serv. Comm'n, 260 Wis. 212, 50 N.W.2d 416 (1951).

83. See cases cited note 3 supra.

84. E.g., Chicago, R.I. \& Pac. Ry. v. Long, 243 Iowa 514, 51 N.W.2d 135 (1952). 
rate cases, which involve utilities or large non-utility corporations. ${ }^{85}$ This discrepancy, where it does exist, may be due to the fact that courts which might be hesitant to disregard the Ben Avon case in a factual situation similar to the original case would be less inclined to do so in a distinguishable situation. This in fact appears to be what has happened to another famous "scope of review" case, Crowell v. Benson, 86 which is now limited in its application to cases factually like the original, although again there is no logical basis for such a restriction. ${ }^{87}$

Even those states which allow a wide scope of review in non-rate utility cases are less inclined to grant such a review to the more numerous and commonplace agency determinations such as license revocations and employers' contributions to unemployment insurance, even though there might be a claim of confiscation involved. ${ }^{88}$ One having a license revoked or an employer contesting his rate of contribution to unemployment insurance would seem to have as much reason to claim confiscation of his property as a utility whose complaint is that the agency order would not allow them to make a "fair" return on property. ${ }^{89}$ The policies considered by the courts in limiting review in these cases would seem to be the same as those in rate cases, e.g., the fear of numerous cases flooding the courts after an agency has been set up to deal with them; but different consequences have ensued, ${ }^{90}$ sometimes as a result of applicable statutes. ${ }^{91}$ At least one state does give an independent review in license revocation cases on the basis of the Ben Avon rule ${ }^{92}$ but such a practice is unusual even among jurisdictions that follow Ben Avon in rate cases. ${ }^{93}$ Positing that the number of cases appealed to the courts concerning individuals would far outnumber the rate cases that might arise (although there is doubt that the people affected by these orders would be as likely to appeal to the courts considering the expense) it would seem that these cases would be less time consuming than rate cases, particularly in light of the amount of

85. Compare Alabama Pub. Serv. Comm'n v. Nunnis, 252 Ala. 30, 39 So.2d 409 (1949) with Alabama Pub. Serv. Comm'n v. Southern Bell Tel. Co., 253 Ala. 1, 42 So.2d 655 (1949), and compare Shupee v. Railroad Comm'n of Texas, 123 Tex. 521, 73 S.W.2d 505 (1939) with Lone Star Gas Co. v. State, 137 Tex. 279, 153 S.W.2d 681 (1941).

86. 285 U.S. 22 (1932).

87. See Schwartz, Does the Ghost of Crowell v. Benson Still Walk? 98 U. OF PA. L. REv. 163 (1949).

88. E.g., Compare Alabama Pub. Serv. Comm'n v. Southern Bell Tel. Co., 253 Ala. 1, 42 So.2d 655 (1949) witk Broadway v. Alabama Dry Dock and Shipbuilding Co., 246 Ala. 201, 20 So.2d 41 (1944).

89. In license revocation cases one must constantly be aware of the "privilegeproperty" dichotomy which cotufronts claims of confiscation. See GeLLHORN, ADministrative Law, Cases and Comments 274 (1947).

90. Compare cases cited note 88 supra with Lowell Gas Co. v. Dep't of Pub. Util., 324 Mass. 80, 84 N.E.2d 811, cert. denied, 338 U.S. 825 (1949) and Opinion of the Justices, 328 Mass. 629, 106 N.E.2d 269 (1952).

91. See Mass. Ans. Laws c. 152, $\$ 11$ (1949).

92. Laisne v. State Board of Optometry, 19 Cal. 2d 831, 123 P.2d 457 (1942).

93. See e.g., MAss. ANn. LAws c. $112, \S \S 64,84$ (1949). See also, Reynolds v. Valentine, 169 Misc. 631,7 N.Y.S.2d 709 (1938); Leach v. Coleman, 188 S.W.2d 220 (Tex. Civ. App. 1945). 
evidence and testimony involved. It is also probable that the courts are more accustomed to handling the types of problems which arise in license revocation cases, for instance, than in cases involving the reasonableness or confiscatory nature of utility rates. ${ }^{94}$

Another reason that might be advanced to explain the limitation of the doctrine to rate cases is that unemployment insurance and many of the types of licensing legislation were later developments in administrative law than rate regulation. ${ }^{95}$ The agencies that handled the latter areas developed at a time when the courts were more accustomed to administrative agencies and more receptive to the theories behind them; therefore, there was less desire to exercise restraint over the agencies to the extent of making an independent review of their orders than there was at the time when the precedents were being established in rate cases. The Ben Avon case was itself a manifestation of a line of thought the Supreme Court had expressed in earlier cases. ${ }^{98}$ There were no such precedents to demand the courts' adherence in deciding the scope of review in unemployment insurance cases and others of that type. This, combined with the growing familiarity of the courts with the policies behind administrative agencies and the development of new theories of administrative law, might be the basis for the distinction as to the type of case to which the Ben Avon rule is applied.

\section{The Practitioner's Problems}

The previous discussion has dealt with the possible reasons why certain states may have adopted the Ben Avon rule in its original or modified form and has attempted to rationalize the differences among the various states, or, more accurately, illustrates that little logical reason exists to substantiate such differences. Some attention must also be given to the practical arguments against following the Ben Avon case. The discussion in this section is largely based upon correspondence, referred to previously, with counsel for utilities and utility commissions.

An argument that is frequently advanced against acceptance of the Ben Avon rule is that once the doctrine is adopted persons affected by an adverse commission order will immediately appeal to the courts and, thus, "[h] earings before the Commission may be transformed into preliminary proceedings ... and the courts ... may emerge as the progenitor

94. "We should have a review of that question, for we should be as competent as the Board to deal with it. . .." L. Hand, J., in NLRB v. Standard Oil Co., 138 F.2d 885, 887 (2d Cir. 1943).

95. Unemployment insurance in the form in which it is now known (a compulsory plan enforced by the state with contributions by the state, and the employer) was a product of the depression and arose in the years 1929 to 1936 . 106 A.L.R. 1531. Licensing, in the widespread form it is known today, is a relatively new development. Council of STATE Governments, Occupational LicensING Legislation IN tHe States 21-4 (1952). Rate making was an earlier development. Alldredge, Rate-Making for Common Carriers 10 (1929).

96. Railroad Commission Cases, 116 U.S. 307 (1886) ; Chicago, M. \& St. P. Ry. v. Minnesota, 134 U.S. 418 (1890). 
of rate-making policies." 97 The conclusion that the Ben Avon rule encourages appeals seems to be borne out by the effects of the reaffirmation of the rule in Massachusetts. ${ }^{98}$ In the thirty years prior to the decision of the Lowell Gas Company case there were no appeals from rate orders in Massachusetts. Since that case there have been three such appeals in a relatively short period of time. ${ }^{99}$ Of course it does not necessarily follow that the Ben Avon rule was responsible for the post-Lowell Gas case appeals, but the inference to that effect is strong and the Commissioner of Public Utilities of Massachusetts believes the rule to be primarily responsible. It is significant that of the Public Utility Commissions answering, all but one preferred not to work under the Ben Avon rule. Furthermore, over half of the attorneys questioned admitted that they would be more likely to appeal from adverse commission orders in a state that followed the Ben Avon case than in jurisdictions which did not.

There is a limitation on the propensity to appeal, however, even in a "pure" Ben Avon state. The costs of litigation during the time taken for agency hearings and retrial of the issues on appeal would seem to act as a deterrent against all but cases with very good chances for success. This factor is naturally of less importance in utility cases than in the few cases arising under the rule which concern persons or businesses with less resources. Assuming that existence of the rule in some form is desired, modification of the rule would seem to be the best answer to the numerous appeals argument. Even though the commission counsels prefer elimination of the rule, they do indicate that a limitation of the evidence that could be heard on appeal to that of the commission record ${ }^{100}$ and a presumption that the commission order was correct ${ }^{101}$ would substantially vitiate the effect of the rule. These modifications would of course minimize chances of reversal of agency orders and would limit the number of appeals. Positing that the company contesting the order is willing to appeal despite the probability that the commission order will be sustained, just what allegations in the complaint will suffice as a claim of confiscation so as to bring the Ben Avon rule into play? There appears to be little in the case or statute law dealing specifically with this problem. Only the usual procedural rules, such as those dealing with summary judgment and the striking of pleadings because they are sham and frivolous are commonly available to strike down groundless claims of confiscation. A complaint sufficient to call for application of the Ben Avon rule has been stated to require the allegation that "the commission's orders result in confiscation

97. Note, 57 Y ALE L.J. 639, 645 (1948).

98. Lowell Gas Co. v. Dep't of Pub. Util., 324 Mass. 80,84 N.E.2d 811, cert. denied, 338 U.S. 825 (1949); Opinion of the Justices, 328 Mass. 679, 106 N.E.2d 269 (1952).

99. From Statement of Commissioner Edward N. Gadsby, representing the Department of Public Utilities, before Joint Legislative Committee on Judiciary relative to House Bill 102 (1951).

100. See text at note 68 supra.

101. See text beginning at Note 64 supra. 
of [complainant's] property in violation of its constitutional right to receive a fair return . . . upon its property . . . specifically alleging the cost of its property . . . the cost of its reproduction, its reasonable value, the maximum rate of return which the rates proscribed will provide . . . and that such rates will not afford a reasonable return on such cost and value. These allegations . . . must be taken at face value. . . ."102 These allegations are specific enough so that the court will be able to discern whether the claim is a groundless one. Claims in licensing cases need not be so specific for they are not so complex and their decision probably does not require any great degree of expertise. Massachusetts has developed a device which would cut down still further on the number of meritless claims of confiscation. This is the imposition of the penalty of double costs on the party contesting the order where there is a finding that the claim was interposed only for the purpose of delaying the effectuation of the order. ${ }^{103}$

The Difference in Presentation of the Case if the Ben Avon Rule is in Effect.-The question was asked of both the counsel for the commissions and the private attorneys who practice before them, whether there would be any differences in the presentation of their case on appeal depending on the existence of the Ben Avon rule in the jurisdiction concerned. Half of the attorneys questioned replied that there would be no difference. The others said that there would be more emphasis placed on the facts, and in effect a complete rehearing of the evidence would follow in the hope that they could get the appellate court to accept their version of the facts. ${ }^{104}$ The counsel for the commissions uniformly felt that there would be marked differences resulting in lengthier trials because of the greater emphasis in re-proving the facts before the appellate court. There would also be a necessary difference in the procedural remedy to be pursued, ${ }^{105}$ and a difference in the burden of proof if the court adopted the "pure" Ben Avon rule in which there would be no presumption of correctness attached to the commission order. ${ }^{106}$ Such differences would indicate the practical difficulty with the Ben Avon rule of unduly involving the agencies in extensive court

102. Staten Island Edison Corp. v. Maltbie, 296 N.Y. 374, 380, 73 N.E.2d 705, 706 (1947), citing Prendergast v. New York Tel. Co., 262 U.S. 93 (1922).

103. Mass. Ann. Laws c. 25, $\$ 5$ (1952).

104. One attorney even went so far as to suggest that if he were in a $B e n$ Avon state, he would withhold evidence from the commission in order to present a more convincing case for reversal on appeal. (This letter is withheld from the Biddle Library files by request of its author.)

105. There are different procedural devices that have to be used depending upon the scope of review afforded the particular agency decision and the statutes relating to judicial procedure in the jurisdiction. For a discussion of the operation of these different remedies in certain states, see Davis, ADMINISTRATrve LAw 718 et seq. (1951) ; Brown, The Use of Extraordinary Legal and Equitable Remedies to Revieze Executive and Administrative Action in Massachusetts, 21 B.U.L. Rev. 632 (1941), 22 B.U.L. Rev. 55 (1942); Riesenfeld, Bauman, and Maxwell, Judicial Control of Administrative Action by Means of the Extraordinary Remedies in Minnesota, 33 Minn. L. Rev. 569, 685 (1949), 36 Minn. L. Rev. 135 (1952).

106. See note 64 supra. 
litigation. This, plus the fact that their own determinations are given little effect, would seem to impair seriously the functions assigned by the legislatures to the agencies.

\section{Conclusion}

The Ben Avon case is of more than "historical interest." Unfortunately, there is no substantive basis upon which to determine whether or not any particular state will adhere to the case. Little in the way of uniformity is evidenced among the states in the reasons advanced for following the case. Perhaps the rationale of Judge Arthur Vanderbilt is the proper one. He has stated that "The state courts of last resort generally are zealous in exercising their duties as modern successors of the Court of King's Bench in superintending. . . agencies particularly where constitutional problems are involved." 107

There is a difficult balance to be struck, to reconcile fear of administrative over-reaching if the scope of review is too limited, and fear that too thorough a judicial review would destroy the very reason for establishing administrative agencies. But the same dilemma exists initially in every branch of administrative law. If the courts have resolved their relations with the agencies in other areas, no reason exists why rate cases should stand as an exception. Furthermore, a reaffirmation or express overruling of Ben Avon by the United States Supreme Court does not seem to be the answer to the problem as some would suggest. It has been shown that a few states have developed the de novo review approach independently, although the initial impetus probably came from the Ben Avon decision.

If there is in fact a need for a "wide" scope of review in cases (and this should not be limited to utility rate cases) where the agency order is allegedly confiscatory, provisions such as those limiting the evidence that can be brought before the court, introducing the presumption that the commission order is correct, and imposing a penalty for bringing groundless claims of confiscation, would seem to alleviate the most feared effects of the Ben Avon case and at the same time strike a balance between the judiciary and the "fourth branch of government."

107. Annual Survey of American Law 205 (1944). 